\title{
Valorization of alcoholic wastes from the vinery industry to produce $\mathrm{H}_{2}$
}

\author{
M.C. Hernández-Soto ${ }^{1}$, J.F. Da Costa-Serra ${ }^{1}$, J. Carratalá $^{2}$, R. Beneito ${ }^{2}$, A. Chica ${ }^{1, *}$ \\ ${ }^{1}$ Instituto de Tecnología Química (Universitat Politècnica de València-Consejo Superior de \\ Investigaciones Científicas), Avd. de los Naranjos s/n, 46022 Valencia (Spain). \\ ${ }^{2}$ Instituto Tecnológico de producto infantil y ocio (AIJU), Avda. de la Industria, 2303440 Ibi, Alicante, \\ (España). \\ *Corresponding author. Tel.: +34 9638770 00-78508; fax: +34 963877809. \\ E-mail address: achica@itq.upv.es
}

\begin{abstract}
This paper focuses on the development of active and stable catalysts for the steam reforming of alcoholic wastes. Two catalysts with high activity in the steam reforming of ethanol have been studied in the steam reforming of an alcoholic waste from the vinery industry, as previous step to their industrial scale up. The catalysts are based on cobalt supported on Zn-hydrotalcite-derived material and natural sepiolite. At laboratory level, the catalytic material based on natural sepiolite showed the best catalytic performance maintaining its catalytic activity for more than 160 hours in presence of $50 \mathrm{ppm}$ of sulfur contained in the alcoholic waste. Thus, sepiolite based catalyst was scaled up to prepare a first generation of catalytic monoliths. The reforming activity of this first generation of monoliths was found lower than their corresponding powdered catalyst. The high calcination temperature $(1573 \mathrm{~K})$ used in the manufacture of the first generation of monoliths was the responsible of their low performance, which was related to the sintering of cobalt catalyst in a larger crystallite size of metallic cobalt. A second generation of monoliths was prepared using a lower calcination temperature $(873 \mathrm{~K})$. Now, the monoliths exhibited a high catalytic performance, similar to the powdered catalyst. The excellent results obtained with the second generation of monoliths have been protected under an invention patent (E201731077). This is the first time that catalytic monoliths based on natural sepiolite promoted with Co are successfully manufactured and tested in the steam reforming of alcoholic wastes from the distillery industry to produce hydrogen.
\end{abstract}

Keywords: Hydrogen production, Cobalt catalysts, Alcoholic waste.

\section{Introduction}

Energy shortage and environmental stress to planet Earth have stimulated our society to find a sustainable alternative to the conventional and non-renewable energy sources (non-RES). Hydrogen as energy carrier could be an environmentally friendly alternative [1-3]. However, hydrogen is currently obtained from nonRES [4]. To solve this problem hydrogen could be produced from a RES by example from biomass derived compounds [5]. Biomass is considered an important source of chemical compounds. Among the large amount of chemical compounds that can be obtained from biomass, ethanol could be an excellent option to produce hydrogen through its steam reforming due to the environmental benefits that it entails, such as the near zero carbon dioxide $\left(\mathrm{CO}_{2}\right)$ emissions, what could help to combat the climate change [6-8]. For that reason, numerous studies have been focused on the design, development and optimization of catalytic materials for ethanol steam reforming (ESR) [9-19]. Among them, Co-based catalysts are widely accepted due to their appropriate low-cost compared to precious metals [20-28]. For the ESR Co has emerged as an active metal catalyst for $\mathrm{C}-\mathrm{C}$ bond scission, which is an important characteristic for the selective production of hydrogen [20]. Moreover, high ethanol conversions over Co catalysts supported on different supports have also been reported [29, 30]. Among them, laminar double hydroxides (LDHs) [31-34] and natural sepiolite [35-38] seem to be the most promised. Although the development of active and stable catalysts for the steam reforming of ethanol has been widely addressed, the steam reforming of alcoholic wastes has 
not been considered properly. The importance of using alcoholic wastes from the wine industry is due to $65 \%$ of world wine production is managed by European winegrowers [39], mostly small and medium-sized wineries. Wine production generates large amounts of solid and liquid wastes, with a serious impact on the environment when they are not adequately treated. The present work aims to raise awareness of the potential of these by-products and their valorization activities. The wineries generate a series of residues such as grape marc, wine lees, surplus wines and wastewater. All the waste that the wineries deliver to the distilleries are processed to obtain purified alcohols, but in this process alcoholic purges without commercial value containing the impurities separated from the good quality alcohols are generated. In this study, a residue from one of these purges has been used for its valorization. This study is part of the Life Ecoelectricity project, whose one of the main objectives is to develop scalable catalytic technologies to produce hydrogen by the steam reforming of theses useless purges. This is the first time that a waste of the waste is used to produce hydrogen by steam reforming reaction. In addition, this is also the first time that catalytic monoliths of natural sepiolite promoted with Co is manufactured and tested in the steam reforming of these alcoholic wastes with high catalytic activity, selectivity and stability.

\section{Experimental}

\subsection{Preparation of catalyst}

Catalyst based on zinc oxide $(\mathrm{ZnO})$ as Co support: this catalyst has been used as a reference material. The incorporation of $\mathrm{Co}$ into the zinc oxide was carried out by incipient wetness impregnation with a solution containing the necessary amount of $\mathrm{Co}\left(\mathrm{NO}_{3}\right)_{2} \cdot 6 \mathrm{H}_{2} \mathrm{O}$ (Sigma-Aldrich, 98\%) to obtain $20 \%$ wt. of Co in the final catalyst. After impregnation, the sample was dried at room temperature for 16 hours and then calcined at $873 \mathrm{~K}$ for $3 \mathrm{~h}$.

Catalyst based on Zn-hydrotalcite (HT) as Co support: HT based catalyst containing Co was obtained from coprecipitation method. Two aqueous solutions, one acid and the other basic, were initially prepared. The acid solution was formed by a mixture of $\mathrm{Zn}\left(\mathrm{NO}_{3}\right)_{2} \cdot 6 \mathrm{H}_{2} \mathrm{O}, \mathrm{Al}\left(\mathrm{NO}_{3}\right)_{3} \cdot 9 \mathrm{H}_{2} \mathrm{O}$ and $\mathrm{Co}\left(\mathrm{NO}_{3}\right)_{2} \cdot 6 \mathrm{H}_{2} \mathrm{O}(\mathrm{Sigma}-$ Aldrich, 98\%) in the adequate proportion to obtain $20 \%$ wt. of Co. The basic solution was formed by a mixture of $\mathrm{NaNO}_{3}$ and $\mathrm{NaOH}$ (Sigma-Aldrich, 98\%). Both solutions were added via a perfusion pump under constant stirring until to obtain a gel which was deposited in a polypropylene bottle and kept in an oven at $333 \mathrm{~K}$ for 18 hours. After, the gel was filtered, washed and dried in an oven at $373 \mathrm{~K}$ overnight. Finally, it was calcined at $873 \mathrm{~K}$ in an oven for 3 hours obtaining the catalysts named as Co-HT.

Catalyst based on natural sepiolite (Sep) as Co support: the incorporation of Co in the natural sepiolite was carried out by the precipitation method. The incorporation was carried out by preparing two solutions, one with the metal, $\mathrm{Co}\left(\mathrm{NO}_{3}\right)_{2} \cdot 6 \mathrm{H}_{2} \mathrm{O}$ (Sigma-Aldrich, 98\%) and the other with sepiolite. Both solutions were brought to $\mathrm{pH}=2$ with the addition of nitric acid (Scharlau, 60\%), to achieve the complete dissolution of the metal, and the suspension of the sepiolite. Then, maintaining the sepiolite in continuous agitation, the solution with the metal was added at a rate of $1 \mathrm{~mL} / \mathrm{min}$ via a perfusion pump. Then a $1 \mathrm{M}$ solution of $\mathrm{NaOH}$ (Sigma-Aldrich, 98\%) was added until reaching a pH of around 9. Finally, it was filtered, washed, dried and calcined at $873 \mathrm{~K}$ in an oven for 3 hours obtaining the Co-Sep.

Part of this study has been focused on testing the catalytic activity of the most optimal material after its shaped (monolith) in the steam reforming of alcoholic wastes in order to scale up for its use in a pilot plant. The manufacture of the catalytic monoliths has been carried out by AIJU as it is described in the patent ES2427715B1.

\subsection{Characterization techniques}

The catalysts used in this study have been subjected to atomic absorption spectrophotometry (AAS) in a Varian Spectra A-10 Plus apparatus to determine the amount of Co.

Textural properties (BET surface area) were measured using an ASAP 2420 apparatus (Micromeritics) at $77 \mathrm{~K}$.

The X-ray diffraction (XRD) has been carried out at room temperature in a Panalytical CubiX diffractometer using $\mathrm{CuK} \alpha$ radiation. 
The reduction behavior was studied by temperature programmed reduction (TPR) in Micromeritics Autochem 2910 equipment.

\subsection{Catalytic study}

Reaction experiments were carried out in a continuous fixed bed reactor at atmospheric pressure, $\mathrm{H}_{2} \mathrm{O} / \mathrm{C}$ molar ratio of 6.5 , WHSV $0.76 \mathrm{~h}^{-1}$ and temperatures $(673-873 \mathrm{~K})$. The reactor was loaded with $0.3 \mathrm{~mL}$ of catalyst $(\sim 0.25 \mathrm{~g})$, diluted with $3 \mathrm{~g}$ of carborundum $(\mathrm{SiC})$. Before reaction the samples were reduced with $\mathrm{H}_{2}\left(100 \mathrm{~mL} \cdot \mathrm{min}^{-1}\right)$ at $873 \mathrm{~K}$ for $2 \mathrm{~h}$. The reaction compounds have been analyzed in a Varian $3800-\mathrm{GC}$. In our previously published article it was showed the equations used to calculate the conversion of ethanol and selectivity to reaction products [22].

An alcoholic waste supplied by Destilerías San Valero has been used in the last part of this paper to carry out the stability studies. The main components of the supplied alcoholic waste were ethanol (91.1 wt. \%) and water (7.3 wt. \%). The presence of the following impurities was also detected: acetaldehyde, ethyl acetate, methanol, n-propanol, 2-propanol, n-buthanol, 2-buthanol, isobuthanol, 2-methyl-1-buhtanol, 3methyl-1-buthanol, ethyl butyrate, acetal, and $\mathrm{SO}_{2}(50 \mathrm{ppm})$. Among them, ethyl acetate and methanol were the most abundant (1.15 wt. \%). Stability tests with this alcoholic waste were carried out at atmospheric pressure, $\mathrm{H}_{2} \mathrm{O} / \mathrm{C}$ of 6.5 (molar ratio), WHSV $0.76 \mathrm{~h}^{-1}$ and at $773 \mathrm{~K}$.

\section{Results and discussion}

\subsection{Catalysts characterization}

In this section is presented the physicochemical characterization of the catalysts studied in this work. In Figure $1 \mathrm{a}$ ) and b) is presented the XRD of the synthesized materials after the calcination and reduction steps. As it can be seen in Figure 1 a) the cobalt phase corresponding to $\mathrm{Co}_{3} \mathrm{O}_{4}$ is detected in all the samples [Ref. code 00-042-1467] [40, 41]. The other identified phases correspond to the materials used as support of the cobalt. These phases are $\mathrm{ZnO}$ [Ref. code 01-089-0510], $\mathrm{ZnAl}_{2} \mathrm{O}_{4}$ [Ref. code 00-005-0669] and sepiolite [Ref. code 00-013-0595].
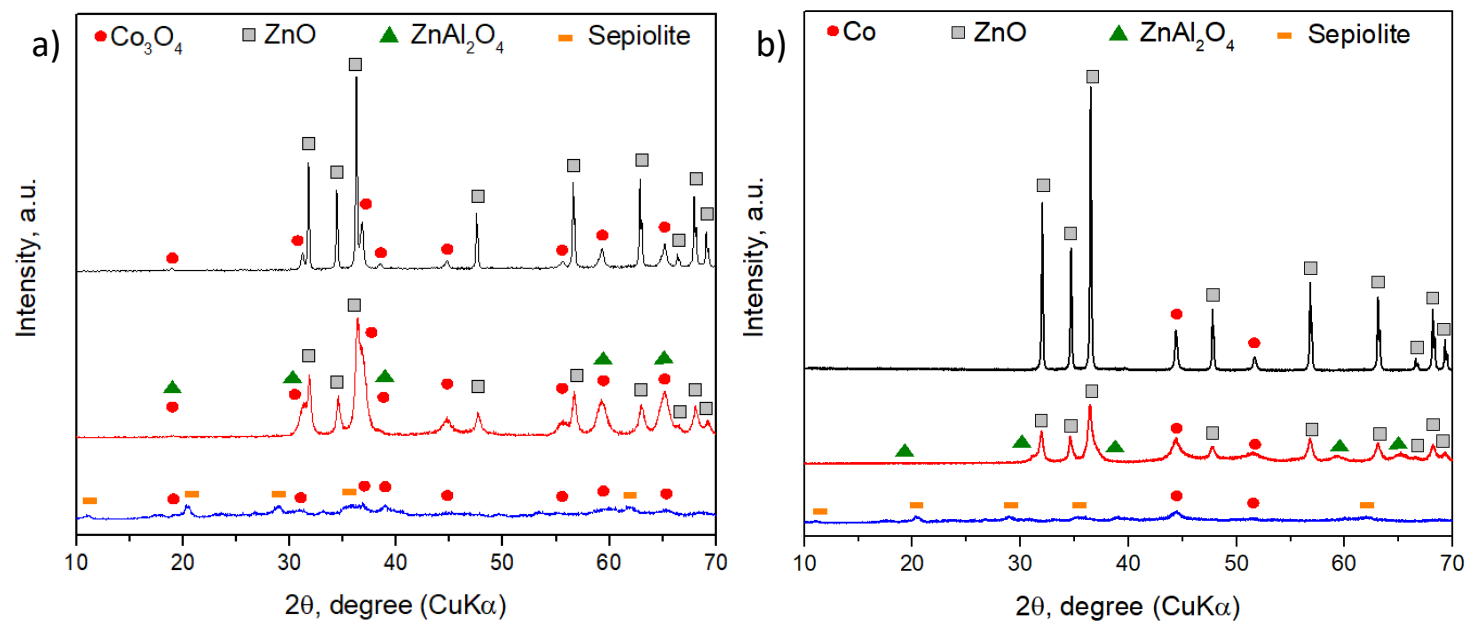

Figure 1. a) XRD of the calcined catalysts. b) XRD of the reduced catalysts.

XRD of the reduced catalysts presented in Figure 1 b) show that after the reduction step, the peaks corresponding to cobalt oxide species disappear and appear those due to the metallic cobalt phase [Ref. code 00-015-0806]. On the other hand, $\mathrm{ZnO}, \mathrm{ZnAl}_{2} \mathrm{O}_{4}$ and sepiolite phases remain unaltered after the reduction step. The treatment of reduction with $\mathrm{H}_{2}$ only affects the Co phase, going from $\mathrm{Co}_{3} \mathrm{O}_{4}$ to $\mathrm{Co}^{0}$, without apparently affecting the oxidized phases present in the supports after the calcination step. 
The crystallite size of $\mathrm{Co}^{0}$ has been determined from the XRD of the reduced catalysts using the Scherrer equation [42]. The average sizes are shown Table 1. As it can be seen the reference catalyst (Co-ZnO) presents the largest crystalline size $(31 \mathrm{~nm})$, while he Co-Sep presents the lowest one $(11 \mathrm{~nm}$ for Co-HT and $8 \mathrm{~nm}$ for Co-Sep).

The amount of Co present in the catalyst and BET surface area have been also determined. As it can be seen in Table 1, the amount of Co is similar for all the catalysts ( $20 \mathrm{wt} . \%)$. In the case of the BET surface area the reference catalyst presents the lowest area $\left(6 \mathrm{~m}^{2} / \mathrm{g}\right)$, while the Co-Sep catalyst exhibits the highest one $\left(112 \mathrm{~m}^{2} / \mathrm{g}\right)$. According to these results, the smaller crystallite size of $\mathrm{Co}^{0}$ present in the Co-Sep catalyst can be correlated with its larger BET surface area since in supports with larger surface it is possible to achieve a better dispersion of the metallic particles achieving a lower size.

Table 1. BET surface area, Co composition and crystalline size of the $\mathrm{Co}^{0}$ determined by XRD for the three catalysts studied in this work.

\begin{tabular}{lccc}
\hline Sample & $\begin{array}{c}\text { BET surface area } \\
\left(\mathbf{m}^{2} / \mathbf{g}\right)\end{array}$ & $\begin{array}{c}\text { Co, wt.\% } \\
\text { Determined by AAS }\end{array}$ & $\begin{array}{c}\mathbf{C o}^{\mathbf{0}} \text { crystallite size (nm) } \\
\text { Determined by XRD }\end{array}$ \\
\hline Co-ZnO & 6 & 19.9 & 31 \\
Co-HT & 35 & 20.5 & 11 \\
Co-Sep & 112 & 15.0 & 8 \\
\hline
\end{tabular}

Once the different phases present in the calcined and reduced catalysts have been identified, the reducibility of these materials has been studied by temperature programmed reduction (TPR). Figure 2 shows the corresponding reduction curves. As it can be seen, two main reduction peaks appear in all the catalysts. These reduction peaks are assigned to the reduction of $\mathrm{Co}_{3} \mathrm{O}_{4}$ to $\mathrm{Co}^{0}$. Specifically, the first peak at low temperature corresponds to the reduction of $\mathrm{Co}_{3} \mathrm{O}_{4}$ to $\mathrm{CoO}$. The second peak at high temperature is assigned to the reduction of $\mathrm{CoO}$ to metallic $\mathrm{Co}^{0}$, as it has been reported by different authors [43, 44]. Important differences have been found for the value of the temperature of each reduction peaks in each catalyst. For the reference catalyst $(\mathrm{Co}-\mathrm{ZnO})$ the first peak appears at $600 \mathrm{~K}$ and the second around $700 \mathrm{~K}$. In the case of the Co-HT catalyst, the first peak appears at $700 \mathrm{~K}$ and the second at $900 \mathrm{~K}$. For this sample both peaks appear at higher reduction temperatures compared to the reference catalyst. Finally, for the Co-Sep catalyst the first peak appears at $600 \mathrm{~K}$ and the second around $1050 \mathrm{~K}$. This sample present the largest separation between the first and second reduction peak. In general, the temperatures of these two peaks are different for the three catalysts, indicating the presence of different Co-support interactions. These differences in the reduction profiles could be also related to the different crystalline size of the $\mathrm{Co}^{0}$ found for each support (Table 1). Smaller crystalline size would be related to stronger metal-support interactions. Indeed, the highest reduction temperatures for the second peak were detected for the Co-Sep catalyst, which exactly showed the smallest $\mathrm{Co}^{0}$ crystallite size. 


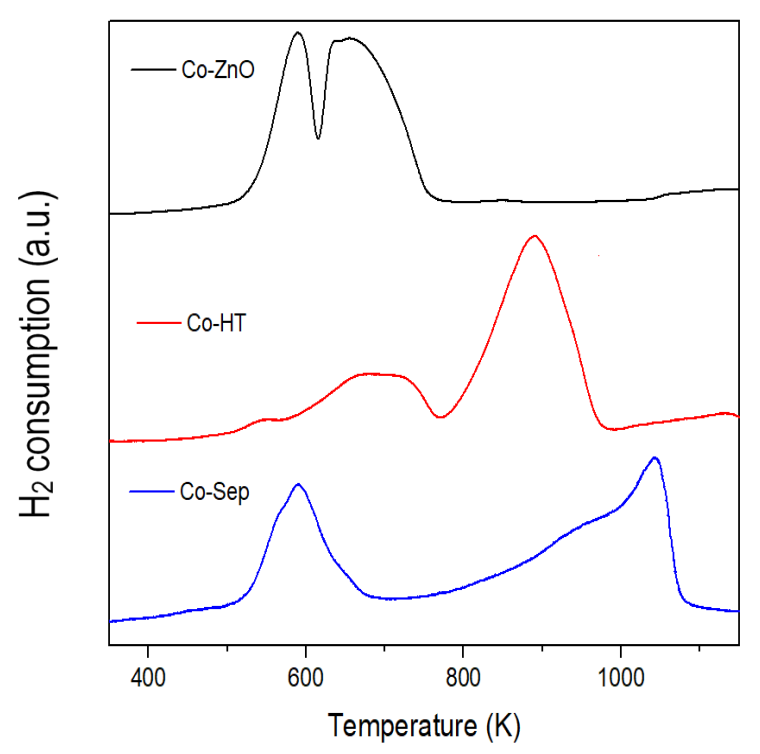

Figure 2. TPR profiles of the catalytic materials studied in this work.

\subsection{Ethanol steam reforming}

The catalytic results presented here correspond to the steady state, achieved after 5 hours of reaction time. Deactivation was not detected along the catalytic experiments. It was verified by re-testing the activity of the catalyst at the end of each experiment coming back to the reaction conditions used at the beginning of each experiment.

Initially the catalytic activity of the three catalysts was studied in the steam reforming of ethanol using a model feed containing 80 vol.\% of water and 20 vol.\% ethanol. Figure 3 a) shows a higher catalytic activity of the Co-based catalysts supported on hydrotalcite and sepiolite compared to the reference catalyst. As it can be seen, Co-HT and Co-Sep exhibited a complete conversion of ethanol in the entire range of reaction temperatures here studied (673-873 K), while the reference catalyst did not achieve conversion values higher than $95 \%$. Referent to the hydrogen selectivity, it can be seen in Figure $3 \mathrm{~b}$ ) that a higher hydrogen production (close to the equilibrium value) is exhibited by the Co-HT and Co-Sep catalysts compared to the reference catalyst.
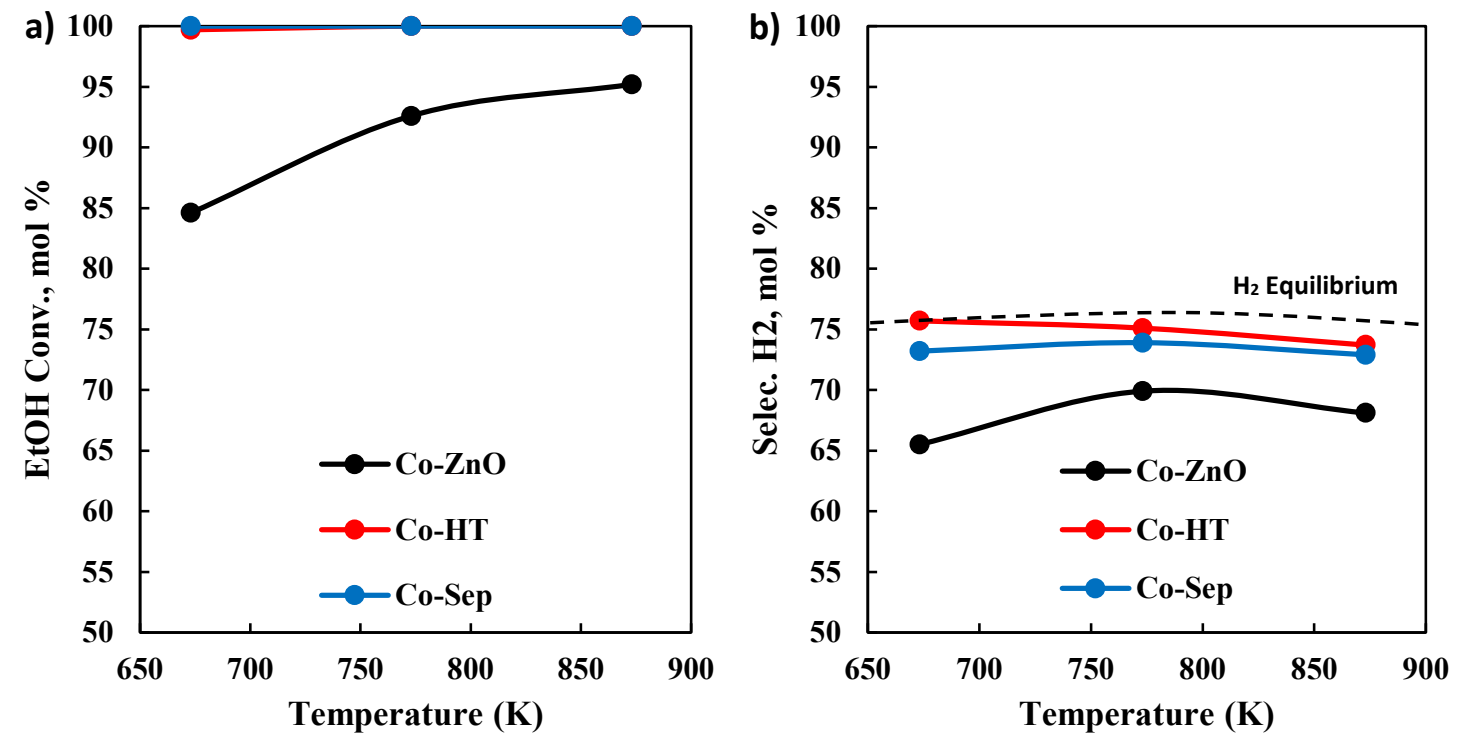

Figure 3. a) Conversion of ethanol versus reaction temperature. b) $\mathrm{H}_{2}$ selectivity versus reaction temperature. Reaction conditions: $\mathrm{H}_{2} \mathrm{O} / \mathrm{C}=6.5$, WHSV $=0.76 \mathrm{~h}^{-1}$ and at atmospheric pressure. 
Regarding to other reaction products, Table 2 shows that lower selectivity of $\mathrm{CO}$ and $\mathrm{CH}_{4}$ are also exhibited by these catalysts. In addition, it should be noted that the presence of unwanted byproducts $\left(\mathrm{C}_{2} \mathrm{H}_{4}\right.$ and $\mathrm{C}_{2} \mathrm{H}_{4} \mathrm{O}$ ) was not detected for hydrotalcite and sepiolite based catalysts. The lower crystalline size of the metallic cobalt presents in these catalysts could justify the high catalytic activity exhibited by these materials. On the other hand, it should be considered that the synthesis methods of these catalysts are quite simple, what would suppose an important benefit from the point of view of their industrial application. For natural sepiolite, it can be pointed out that Spain is one of the main worldwide producers, so an abundant and cheap raw material would be available.

Table 2. Reaction data obtained in the steam reforming of a model ethanol feed ( $80 \mathrm{vol} \% \mathrm{H}_{2} \mathrm{O}$ and 20 vol.\% Ethanol). Reaction conditions: $\mathrm{H}_{2} \mathrm{O} / \mathrm{C}=6.5$, WHSV $=0.76 \mathrm{~h}^{-1}$ and at atmospheric pressure.

\begin{tabular}{lcccccc}
\hline \multirow{2}{*}{ Catalyst } & \multirow{2}{*}{$\mathbf{T}(\mathbf{K})$} & \multicolumn{5}{c}{ Selectivity, \% mol } \\
\cline { 3 - 7 } & & $\mathbf{C H}_{\mathbf{4}}$ & $\mathbf{C O}$ & $\mathbf{C O}_{\mathbf{2}}$ & $\mathbf{C}_{2} \mathbf{H}_{\mathbf{4}}$ & $\mathbf{C}_{2} \mathbf{H}_{\mathbf{4}} \mathbf{O}$ \\
\hline \multirow{3}{*}{ Co-ZnO } & 673 & 6.4 & 6.9 & 16.6 & 0.2 & 4.4 \\
& 773 & 3.6 & 3.0 & 22.8 & 0.1 & 0.6 \\
& 873 & 3.8 & 9.2 & 18.6 & 0.1 & 0.2 \\
Co-HT & 673 & 4.9 & 1.0 & 18.4 & 0.0 & 0.0 \\
& 773 & 0.9 & 2.2 & 21.7 & 0.0 & 0.0 \\
& 873 & 1.1 & 3.0 & 21.2 & 0.0 & 0.0 \\
Co-Sep & 673 & 4.5 & 0.7 & 21.5 & 0.0 & 0.0 \\
& 773 & 3.1 & 2.3 & 20.7 & 0.0 & 0.0 \\
& 873 & 2.9 & 4.9 & 19.2 & 0.0 & 0.0 \\
\hline
\end{tabular}

\subsection{Steam reforming of alcoholic waste from distillery industries}

Considering the excellent catalytic performance exhibited by the Co-based catalysts supported on HT and sepiolite, they were tested in the steam reforming of an alcoholic waste in order to explore their catalytic potential to be applied industrially. Alcoholic wastes from wine production were supplied by Destilerías San Valero. The main components of the selected alcoholic waste are presented in Table 3. Before the reforming experiments, the alcoholic waste was mixed with water in order to achieve a $\mathrm{H}_{2} \mathrm{O} / \mathrm{C}$ ratio of 6.5.

Table 3. Composition of the alcoholic waste supplied by Destilerías San Valero.

\begin{tabular}{lc}
\hline \multicolumn{1}{c}{ Compound } & Concentration, wt. \% \\
\hline Ethanol & 91.1 \\
$\mathrm{H}_{2} \mathrm{O}$ & 7.3 \\
\hline Impurities & Concentration, mg/L \\
\hline Acetaldehyde & 330.8 \\
Methanol & 2888.5 \\
2-Propanol & 10.7 \\
N-Propanol & 5.5 \\
Ethyl acetate & 8644.8 \\
2-Buthanol & 38.7 \\
Isobuthanol & 4.1 \\
N-Buthanol & 9.9 \\
2-Methyl-1-Buthanol & 7.1 \\
3-Methyl-1-Buthanol & 13.5 \\
Acetal & 54.3 \\
Ethyl Butyrate & 247.7 \\
$\mathrm{SO}_{2}$ & 50 \\
\hline
\end{tabular}


Table 4 shows the catalytic activity of the catalysts. As it can be seen, Co-Sep presents a high catalytic activity, even at low reaction temperatures $(673 \mathrm{~K})$. Ethanol and impurities present in the alcoholic waste were totally reformed at $773 \mathrm{~K}$ in both catalysts. Regarding to the products distribution, Co-HT catalyst showed the highest selectivity to $\mathrm{H}_{2}$ and the lowest production of $\mathrm{CO}$ and $\mathrm{CH}_{4}$. However, this catalyst showed a higher production of undesired byproducts such as $\mathrm{C}_{2} \mathrm{H}_{4}, \mathrm{C}_{2} \mathrm{H}_{4} \mathrm{O}$ and $\mathrm{C}_{3} \mathrm{H}_{6} \mathrm{O}$. For the Co-Sep catalyst, the formation of these byproducts was very low, especially at high temperatures $(773 \mathrm{~K})$ where the formation of these byproducts is not detected in the outlet stream. This fact is very important when a possible industrial application is being considered.

Table 4. Catalytic activity and products selectivity in the steam reforming of alcoholic waste. Reaction conditions $\mathrm{H}_{2} \mathrm{O} / \mathrm{C}=6.5$, $\mathrm{WHSV}=0.76 \mathrm{~h}^{-1}$ and at atmospheric pressure

\begin{tabular}{|c|c|c|c|c|c|c|c|c|c|}
\hline \multirow{2}{*}{ Catalyst } & \multirow{2}{*}{$\mathbf{T}(\mathbf{K})$} & \multirow{2}{*}{ Conv., mol \% } & \multicolumn{7}{|c|}{ Selectivity, mol \% } \\
\hline & & & $\mathrm{CH}_{4}$ & $\mathrm{CO}$ & $\mathrm{CO}_{2}$ & $\mathbf{H}_{2}$ & $\mathrm{C}_{2} \mathrm{H}_{4}$ & $\mathrm{C}_{2} \mathrm{H}_{4} \mathrm{O}$ & $\mathrm{C}_{3} \mathrm{H}_{6} \mathrm{O}$ \\
\hline \multirow{3}{*}{ Co-HT } & 673 & 67.7 & 3.7 & 2.5 & 16.0 & 74.3 & 0.0 & 3.0 & 0.5 \\
\hline & 773 & 100.0 & 0.9 & 2.7 & 18.5 & 76.8 & 0.1 & 0.0 & 1.0 \\
\hline & 873 & 100.0 & 1.7 & 5.2 & 15.5 & 76.9 & 0.1 & 0.0 & 0.6 \\
\hline \multirow{3}{*}{ Co-Sep } & 673 & 100.0 & 9.7 & 16.1 & 7.9 & 65.8 & 0.0 & 0.5 & 0.0 \\
\hline & 773 & 100.0 & 3.1 & 1.9 & 19.1 & 75.9 & 0.0 & 0.0 & 0.0 \\
\hline & 873 & 100.0 & 2.8 & 5.3 & 16.9 & 75.0 & 0.0 & 0.0 & 0.0 \\
\hline
\end{tabular}

Stability of these two catalysts has been also explored carrying out studies at long reaction times. Figure 4 a) shows that after 15 hours of reaction time deactivation begins to be evident for Co-HT catalyst. However, the deactivation could be considered small since it is under $2 \%$. In the case of Co-Sep, Figure $4 \mathrm{~b}$ ), the activity remains stable for 168 hours. Nevertheless, after 75 hours of reaction time acetaldehyde $\left(\mathrm{C}_{2} \mathrm{H}_{4} \mathrm{O}\right)$ begins to be detected, increasing gradually until reaching percentages of $0.5 \%$. This data is important, since the presence of acetaldehyde is indicative that the deactivation of the catalyst has begun. The rest of the reaction products remain constant over time, highlighting the high selectivity to hydrogen.
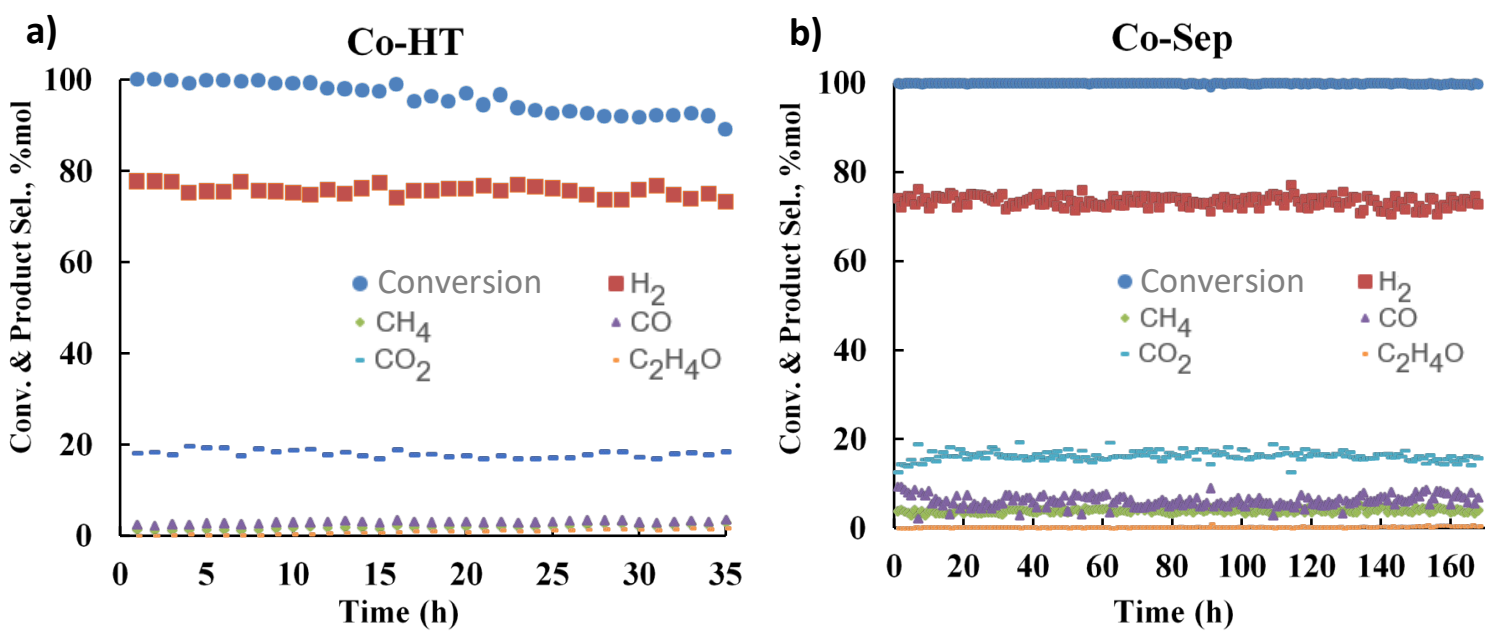

Figure 4. a) Catalytic activity of Co-HT catalyst and products selectivity in the steam reforming of the alcoholic waste versus reaction time. b) Catalytic activity of Co-Sep catalyst and products selectivity in the steam reforming of the alcoholic waste versus reaction time. Reaction conditions $773 \mathrm{~K}, \mathrm{H}_{2} \mathrm{O} / \mathrm{C}=6.5$, WHSV $=0.76 \mathrm{~h}^{-1}$ and atmospheric pressure. 


\subsection{Conformation of the catalyst for steam reforming of alcoholic waste}

As it has been shown in the previous section, Co-Sep catalyst exhibited the best catalytic performance, possibly due to its more adequate physicochemical properties (higher BET area and smaller size of Co metal particle (Table 1). Thus, the following step was to carry out the scaling up of the catalyst for its industrial application. A first generation of monoliths of Co-Sep was manufactured by AIJU following its own patent ES2427715B1. Manufactured monoliths were calcined at $1573 \mathrm{~K}$. Catalytic activity of the first generation of monoliths was studied in the steam reforming of the selected alcoholic waste. Table 5 shows the catalytic results. As it can be seen, the conversion of the alcoholic waste was lower than expected, being the production of acetaldehyde quite high. In order to know the low catalytic performance exhibited by the first generation of monoliths, characterization of the monoliths by XRD was carried out. It was found larger crystallite size of $\mathrm{Co}^{0}(20 \mathrm{~nm})$ than in the powdered catalyst $(8 \mathrm{~nm}$, Table 1$)$, suggesting that sinterization of the metallic cobalt is occurring. The increasing of the crystalline size of the metallic cobalt by sinterization process is explained by the high temperature used in the manufacture of this first generation of monoliths $(1573 \mathrm{~K})$. Thus, it was decided to prepare a second generation using a lower temperature of calcination $(873 \mathrm{~K})$. The second generation of monoliths were also tested in the reforming of the alcoholic waste. The results are shown also in Table 5. Now the monoliths show a higher catalytic activity and selectivity to $\mathrm{H}_{2}$, similar to those exhibited by the powdered catalyst (Table 4).

Table 5. Catalytic activity and product selectivity of the first and second generation of Co-Sep monoliths in the steam reforming of the alcoholic waste versus reaction time. Reaction conditions $\mathrm{H}_{2} \mathrm{O} / \mathrm{C}=6.5$, WHSV $=0.76 \mathrm{~h}^{-1}$ and at atmospheric pressure.

\begin{tabular}{|c|c|c|c|c|c|c|c|c|c|}
\hline \multirow{2}{*}{ Catalyst } & \multirow{2}{*}{$\mathbf{T}(\mathrm{K})$} & \multirow{2}{*}{ Conv., mol \% } & \multicolumn{7}{|c|}{ Selectivity, mol \% } \\
\hline & & & $\mathrm{CH}_{4}$ & $\mathrm{CO}$ & $\mathrm{CO}_{2}$ & $\mathbf{H}_{2}$ & $\mathrm{C}_{2} \mathrm{H}_{4}$ & $\mathrm{C}_{2} \mathrm{H}_{4} \mathrm{O}$ & $\mathrm{C}_{3} \mathrm{H}_{6} \mathrm{O}$ \\
\hline \multirow{3}{*}{$\begin{array}{l}\text { Co-Sep }(1573 \text { K) } \\
\text { (First Generation) }\end{array}$} & 673 & 17.3 & 0.1 & 0.0 & 3.7 & 42.4 & 1.4 & 52.4 & 0.0 \\
\hline & 773 & 64.8 & 0.8 & 0.2 & 1.6 & 52.1 & 1.0 & 44.0 & 0.3 \\
\hline & 873 & 86.1 & 1.1 & 0.2 & 1.8 & 40.5 & 1.8 & 54.5 & 0.1 \\
\hline \multirow{3}{*}{$\begin{array}{c}\text { Co-Sep (873 K) } \\
\text { (Second Generation) }\end{array}$} & 673 & 100.0 & 10.4 & 19.7 & 5.7 & 63.3 & 0.0 & 0.8 & 0.1 \\
\hline & 773 & 100.0 & 3.9 & 2.3 & 19.9 & 73.9 & 0.0 & 0.0 & 0.0 \\
\hline & 873 & 100.0 & 3.6 & 7.5 & 14.6 & 74.3 & 0.0 & 0.0 & 0.0 \\
\hline
\end{tabular}

The excellent results obtained with the second generation of monoliths have been protected under an invention patent (E201731077). In addition, massive manufacture of monoliths is being carried out (3 kg) to be used in the steam reforming pilot plant, which is being built within the Life-ECOELECTRICIY project.

\section{Conclusions}

It has been prepared Co-HT and Co-Sep catalysts highly active and selectivity in the steam reforming of ethanol and alcoholic wastes from distillery industries. Co-Sep catalyst showed the highest stability in the reforming of selected alcoholic waste, being able to maintain the complete conversion of alcoholic compounds for more than $160 \mathrm{~h}$ of reaction time, despite of the presence of sulfur (50 ppm). Probably, its more adequate physicochemical properties (higher BET area and smaller crystalline size of metallic cobalt) account for its excellent catalytic performance. Thus, this catalyst was selected for its scaled up and application an industrial level. Monoliths of Co-Sep were manufactured according to the patent ES2427715B1. The calcination temperature during the monolith manufacture had a great impact in the final catalytic activity of the monolith. High calcination temperatures $(1573 \mathrm{~K})$ lead to low active monoliths due to a sinterization of the metallic cobalt particles. However, the monoliths calcined at $873 \mathrm{~K}$ exhibited a high catalytic activity, hydrogen selectivity and stability. Therefore, this methodology was selected for the manufacture of 3 kilogram of Co-Se monoliths. These monoliths will be used in a pilot plant that is being built within the Life-ECOELECTRICIY project. 
The results presented in this study show, by the first time, the development of catalytic monoliths based on natural sepiolite promoted with cobalt with high catalytic activity, selectivity and stability in steam reforming of alcoholic wastes from the distillery industry without commercial value.

\section{Acknowledgements}

The doctor Javier Francisco Da Costa Serra acknowledges to the Life-Ecoelectricity project for the awarded research contract. Life-ECOELECTRICITY consortium acknowledges the Life Program for funding the Life-ECOELECTRICITY project. The doctor Antonio Chica acknowledges to the RED DE EXCELENCIA EN BIORREFINERIAS SOSTENIBLES for the support.

\section{References}

[1] Liguras DK, Kondarides DI, Verykios XE. Production of hydrogen for fuel cells by steam reforming of ethanol over supported noble metal catalysts. Applied Catalysis B: Environmental. 2003;43:345-54.

[2] Sohn H, Ozkan US. Cobalt-Based Catalysts for Ethanol Steam Reforming: An Overview. Energy \& Fuels. 2016;30:5309-22.

[3] da Silva Veras T, Mozer TS, da Costa Rubim Messeder dos Santos D, da Silva César A. Hydrogen: Trends, production and characterization of the main process worldwide. International Journal of Hydrogen Energy. 2017;42:2018-33.

[4] Muradov N. Low to near-zero $\mathrm{CO}_{2}$ production of hydrogen from fossil fuels: Status and perspectives. International Journal of Hydrogen Energy. 2017;42:14058-88.

[5] Ma F, Hanna MA. Biodiesel production: a review1. Bioresource Technology. 1999;70:1-15.

[6] Maggio G, Freni S, Cavallaro S. Light alcohols/methane fuelled molten carbonate fuel cells: a comparative study. Journal of Power Sources. 1998;74:17-23.

[7] F. Brown L. A comparative study of fuels for on-board hydrogen production for fuel-cell-powered automobiles. International Journal of Hydrogen Energy. 2001;26:381-97.

[8] Ni M, Leung DYC, Leung MKH, Sumathy K. An overview of hydrogen production from biomass. Fuel Processing Technology. 2006;87:461-72.

[9] Haryanto A, Fernando S, Murali N, Adhikari S. Current Status of Hydrogen Production Techniques by Steam Reforming of Ethanol: A Review. Energy \& Fuels. 2005;19:2098-106.

[10] Huber GW, Iborra S, Corma A. Synthesis of Transportation Fuels from Biomass: Chemistry, Catalysts, and Engineering. Chemical Reviews. 2006;106:4044-98.

[11] Ni M, Leung DYC, Leung MKH. A review on reforming bio-ethanol for hydrogen production. International Journal of Hydrogen Energy. 2007;32:3238-47.

[12] Nimmas T, Jamrunroj P, Wongsakulphasatch S, Kiatkittipong W, Laosiripojana N, Gong J, et al. Influence of $\mathrm{CaO}$ precursor on $\mathrm{CO}_{2}$ capture performance and sorption-enhanced steam ethanol reforming. International Journal of Hydrogen Energy. 2018.

[13] Shao J, Zeng G, Li Y. Effect of Zn substitution to a $\mathrm{LaNiO}_{3-\delta}$ perovskite structured catalyst in ethanol steam reforming. International Journal of Hydrogen Energy. 2017;42:17362-75.

[14] Aceves Olivas DY, Baray Guerrero MR, Escobedo Bretado MA, Marques da Silva Paula M, Salinas Gutiérrez J, Guzmán Velderrain V, et al. Enhanced ethanol steam reforming by $\mathrm{CO}_{2}$ absorption using $\mathrm{CaO}$, $\mathrm{CaO} * \mathrm{MgO}$ or $\mathrm{Na}_{2} \mathrm{ZrO}_{3}$. International Journal of Hydrogen Energy. 2014;39:16595-607.

[15] Compagnoni M, Tripodi A, Di Michele A, Sassi P, Signoretto M, Rossetti I. Low temperature ethanol steam reforming for process intensification: New Ni/MxO- $\mathrm{ZrO}_{2}$ active and stable catalysts prepared by flame spray pyrolysis. International Journal of Hydrogen Energy. 2017;42:28193-213.

[16] Agüero FN, Morales MR, Larrégola S, Izurieta EM, Lopez E, Cadús LE. $\mathrm{La}_{1-\mathrm{x}} \mathrm{Ca}_{\mathrm{x}} \mathrm{Al}_{1-\mathrm{y}} \mathrm{Ni}_{\mathrm{y}} \mathrm{O}_{3}$ perovskites used as precursors of nickel based catalysts for ethanol steam reforming. International Journal of Hydrogen Energy. 2015;40:15510-20.

[17] Sharma PK, Saxena N, Roy PK, Bhatt A. Hydrogen generation by ethanol steam reforming over $\mathrm{Rh} / \mathrm{Al}_{2} \mathrm{O}_{3}$ and $\mathrm{Rh} / \mathrm{CeZrO}_{2}$ catalysts: A comparative study. International Journal of Hydrogen Energy. 2016;41:6123-33.

[18] He S, Mei Z, Liu N, Zhang L, Lu J, Li X, et al. Ni/SBA-15 catalysts for hydrogen production by ethanol steam reforming: Effect of nickel precursor. International Journal of Hydrogen Energy. 2017;42:14429-38.

[19] Hou J, Liu Z-M, Lin G-D, Zhang H-B. Novel Ni- $\mathrm{ZrO}_{2}$ catalyst doped with $\mathrm{Yb}_{2} \mathrm{O}_{3}$ for ethanol steam reforming. International Journal of Hydrogen Energy. 2014;39:1315-24. 
[20] Vaidya PD, Rodrigues AE. Insight into steam reforming of ethanol to produce hydrogen for fuel cells. Chemical Engineering Journal. 2006;117:39-49.

[21] de la Peña O’Shea VA, Nafria R, Ramírez de la Piscina P, Homs N. Development of robust Co-based catalysts for the selective H2-production by ethanol steam-reforming. The Fe-promoter effect. International Journal of Hydrogen Energy. 2008;33:3601-6.

[22] Da Costa-Serra JF, Chica A. Bioethanol steam reforming on Co/ITQ-18 catalyst: Effect of the crystalline structure of the delaminated zeolite ITQ-18. International Journal of Hydrogen Energy. 2011;36:3862-9.

[23] Palma V, Castaldo F, Ciambelli P, Iaquaniello G, Capitani G. On the activity of bimetallic catalysts for ethanol steam reforming. International Journal of Hydrogen Energy. 2013;38:6633-45.

[24] Yu S-W, Huang H-H, Tang C-W, Wang C-B. The effect of accessible oxygen over $\mathrm{Co}_{3} \mathrm{O}_{4}-\mathrm{CeO}_{2}$ catalysts on the steam reforming of ethanol. International Journal of Hydrogen Energy. 2014;39:20700-11. [25] Contreras JL, Salmones J, Colín-Luna JA, Nuño L, Quintana B, Córdova I, et al. Catalysts for H2 production using the ethanol steam reforming (a review). International Journal of Hydrogen Energy. 2014;39:18835-53.

[26] Zhao X, Lu G. Modulating and controlling active species dispersion over Ni-Co bimetallic catalysts for enhancement of hydrogen production of ethanol steam reforming. International Journal of Hydrogen Energy. 2016;41:3349-62.

[27] Ando Y, Matsuoka K. Role of $\mathrm{Fe}$ in $\mathrm{Co}-\mathrm{Fe}$ particle catalysts for suppressing $\mathrm{CH}_{4}$ production during ethanol steam reforming for hydrogen production. International Journal of Hydrogen Energy. 2016;41:12862-8.

[28] Chiou JYZ, Siang J-Y, Yang S-Y, Ho K-F, Lee C-L, Yeh C-T, et al. Pathways of ethanol steam reforming over ceria-supported catalysts. International Journal of Hydrogen Energy. 2012;37:13667-73.

[29] Mattos LV, Jacobs G, Davis BH, Noronha FB. Production of Hydrogen from Ethanol: Review of Reaction Mechanism and Catalyst Deactivation. Chemical Reviews. 2012;112:4094-123.

[30] Da Costa-Serra JF, Chica A. Catalysts based on Co-Birnessite and Co-Todorokite for the efficient production of hydrogen by ethanol steam reforming. International Journal of Hydrogen Energy. 2018;43:16859-65.

[31] Mas V, Dieuzeide ML, Jobbágy M, Baronetti G, Amadeo N, Laborde M. Ni(II)-Al(III) layered double hydroxide as catalyst precursor for ethanol steam reforming: Activation treatments and kinetic studies. Catalysis Today. 2008;133-135:319-23.

[32] Romero A, Jobbágy M, Laborde M, Baronetti G, Amadeo N. Ni(II)-Mg(II)-Al(III) catalysts for hydrogen production from ethanol steam reforming: Influence of the activation treatments. Catalysis Today. 2010;149:407-12.

[33] Vizcaíno AJ, Lindo M, Carrero A, Calles JA. Hydrogen production by steam reforming of ethanol using $\mathrm{Ni}$ catalysts based on ternary mixed oxides prepared by coprecipitation. International Journal of Hydrogen Energy. 2012;37:1985-92.

[34] Romero A, Jobbágy M, Laborde M, Baronetti G, Amadeo N. Ni(II)-Mg(II)-Al(III) catalysts for hydrogen production from ethanol steam reforming: Influence of the $\mathrm{Mg}$ content. Applied Catalysis $\mathrm{A}$ : General. 2014;470:398-404.

[35] Menor M, Sayas S, Chica A. Natural sepiolite promoted with Ni as new and efficient catalyst for the sustainable production of hydrogen by steam reforming of the biodiesel by-products glycerol. Fuel. 2017;193:351-8.

[36] Liu S, Chen M, Chu L, Yang Z, Zhu C, Wang J, et al. Catalytic steam reforming of bio-oil aqueous fraction for hydrogen production over Ni-Mo supported on modified sepiolite catalysts. International Journal of Hydrogen Energy. 2013;38:3948-55.

[37] Sayas S, Chica A. Furfural steam reforming over Ni-based catalysts. Influence of Ni incorporation method. International Journal of Hydrogen Energy. 2014;39:5234-41.

[38] Liang T, Wang Y, Chen M, Yang Z, Liu S, Zhou Z, et al. Steam reforming of phenol-ethanol to produce hydrogen over bimetallic NiCu catalysts supported on sepiolite. International Journal of Hydrogen Energy. 2017;42:28233-46.

[39] European Wine: a solid pillar of the European Union economy. In: Vins- CCEdE, editor. http://www.ceev.eu/about-the-eu-wine-sector2016.

[40] Velu S, Suzuki K. Synthesis and characterization of a new Sn-incorporated CoAl-layered double hydroxide $(\mathrm{LDH})$ and catalytic performance of Co-spinel microcrystallites in the partial oxidation of methanol. In: Sayari A, Jaroniec M, editors. Studies in Surface Science and Catalysis: Elsevier; 2000. p. 451-8.

[41] Wang S-F, Sun G-Z, Fang L-M, Lei L, Xiang X, Zu X-T. A comparative study of $\mathrm{ZnAl}_{2} \mathrm{O}_{4}$ nanoparticles synthesized from different aluminum salts for use as fluorescence materials. Scientific Reports. 2015;5:12849. 
[42] Cullity BD. Elements of X-ray Diffraction. In: Company AWP, editor.1956. p. 261-2.

[43] Guil-López R, Navarro RM, Peña MA, Fierro JLG. Hydrogen production by oxidative ethanol reforming on $\mathrm{Co}, \mathrm{Ni}$ and $\mathrm{Cu}$ ex-hydrotalcite catalysts. International Journal of Hydrogen Energy. 2011;36:1512-23.

[44] Da Costa-Serra JF, Guil-López R, Chica A. Co/ZnO and $\mathrm{Ni} / \mathrm{ZnO}$ catalysts for hydrogen production by bioethanol steam reforming. Influence of $\mathrm{ZnO}$ support morphology on the catalytic properties of $\mathrm{Co}$ and $\mathrm{Ni}$ active phases. International Journal of Hydrogen Energy. 2010;35:6709-16. 